\title{
Evaluation of stallion sperm motility with ImageJ using a cell phone camera and a light microscope
}

\author{
[Avaliação da motilidade espermática de garanhões com ImageJ usando-se câmera de \\ celular e microscópio óptico] \\ G.P. Freitag ${ }^{1}$ L.G.F. Lima $^{1}$, L.E. Kozicki ${ }^{1}$, L.C.S. Felicio ${ }^{1}$, R.R. Weiss ${ }^{2}$ \\ ${ }^{1}$ Aluno de pós-graduação - Faculdade de Ciências da Vida - Pontifícia Universidade \\ Católica do Paraná - Curitiba, PR \\ ${ }^{2}$ Faculdade de Veterinária - Universidade Federal do Paraná - Curitiba, PR
}

\begin{abstract}
This study aimed to determine the accuracy of assessing stallion sperm motility using a light microscope, a cell phone camera, and a free computer-assisted semen analysis (FCASA) package for ImageJ. The total motility of frozen $(n=22)$ and cooled $(n=48)$ equine semen was determined by FCASA and compared to the results of subjective visual analysis (SVA) by two technicians. Frozen samples were also evaluated by a commercial computer-assisted semen analysis (CCASA) system. The Friedman test revealed no significant differences $(\mathrm{P}>0.05)$ between cooled samples analyzed by FCASA (38.0) and SVA (technician 1, 40.0; technician $2,40.0)$, nor between frozen samples analyzed by FCASA $(23.36 \pm 15.9)$, SVA $(25.5 \pm 18.8$ and $25.8 \pm 18.5)$, and CCASA $(25.2 \pm 18.3)$. However, mean FCASA results were underestimated by $7.2 \%$ compared with CCASA. The correlation between FCASA and CCASA was significant and strong (P < $0.0001, \mathrm{r}=0.95)$. Chi-squared tests indicated that FCASA provided similar results $(\mathrm{P}=0.14)$ to the reference method (CCASA), but SVA had lower accuracy ( $\mathrm{P}=0.04)$. ImageJ analysis of cell phone videos captured under a light microscope can be used for estimation of stallion sperm motility with comparable accuracy to commercial systems.
\end{abstract}

Keywords: semen, horse, total motility, sperm analysis, smartphone.

\section{RESUMO}

O objetivo deste estudo foi testar as configurações necessárias para avaliar a motilidade espermática total de garanhões, mediante o uso de ImageJ, microscópio óptico e câmera de celular. Os valores de motilidade total das amostras de sêmen equino congeladas (22) e refrigeradas (48) foram comparados por análise visual (SVA) e pelo plugin do ImageJ (CASAF). Amostras congeladas também foram comparadas por um CASA comercial (CCASA). O teste de Friedman não resultou em diferença estatística $(P>0,05)$ entre as 48 amostras analisadas com CASAF (38,0) e SVA de dois avaliadores $(40,0$ e 40,0). A comparação das 22

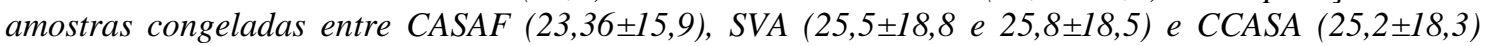
também não resultou em diferença estatística, sendo que a média dos resultados obtidos com CASAF subestimou a obtida com o CCASA em 7,2\%. A correlação entre CASAF e CCASA foi significativamente elevada $(r=0,95, P<0,0001)$. O teste de qui-quadrado resultou em proporção de acertos semelhantes entre $o$ CASAF e o CCASA $(P=0,14)$, enquanto SVA resultou em proporção diferente $(P=0,04)$, indicando menor acurácia. $O$ uso de microscópio óptico e câmera de celular foi útil para obter vídeos de sêmen de garanhões a serem analisados com ImageJ, proporcionando resultados de motilidade total equiparáveis a sistemas comerciais.

Palavras-chave: sêmen, cavalos, motilidade total, análise do sêmen, smartphone

Recebido em 21 de fevereiro de 2020

Aceito em 2 de julho de 2020

E-mail: giovanna_w7@hotmail.com 


\section{INTRODUCTION}

Evaluation of sperm motility is of great importance for animal reproduction (Love, 2011; McKinnon et al., 2011). Sperm motility alone cannot be used to predict the potential fertility of males; nevertheless, it is essential for the success of widely used breeding techniques, such as artificial insemination and cryopreservation (Kuisma et al., 2006; Amann and Waberski, 2014).

Motility can be assessed visually (subjective method) or by computer-assisted sperm analysis (CASA). The subjective method can result in variations of about $30-60 \%$ because of differences in the training and experience of technicians (Linford et al., 1976; Neuwinger et al., 1990; Verstegen et al., 2002). CASA was developed to reduce subjectivity in motility evaluation by objective computer-assisted identification of sperm cells (Amann and Hamerstedt, 1980; Amann and Waberski, 2014). The system identifies and tracks cells automatically, generating important and accurate data on individual cell kinetics (Verstegen et al., 2002; Amann and Katz, 2004). This technology is essential for training technicians and advancing research because of the large number of cells involved. It is more precise than the human eye and capable of detecting subtle changes in sperm parameters (Whitesell et al., 2014; Lu et al., 2014; Elsayed et al., 2015).

CASA is not widely used in veterinary science because of the associated high costs (Giaretta et al., 2017) and need for standardization. The technique is mainly applied in large facilities focused on research (Verstegen et al., 2002; Klimowicz et al., 2008). The recommendation is to use a phase-contrast microscope and a highspeed camera (high number of frames per second) to allow the software to detect sperm cells and their movement patterns (Amann and Katz, 2004; Amann and Waberski, 2014; Elsayed et al., 2015). CASA systems are very sensitive to slight changes in operational settings, leading to differences between results. For instance, results may be largely affected by illumination, camera frame rate, sample concentration, or type of chamber (Verstegen et al., 2002; Amann and Waberski, 2014). Therefore, it is important to adequately standardize the settings for each animal species and account for differences between CASA algorithms (Verstegen et al., 2002; Schleh and Leoni, 2013; Amann and Waberski, 2014).

Amann and Waberski (2014) suggested the development of an economically feasible, portable CASA system capable of evaluating sperm motion and some morphologic attributes for use by field theriogenologists. Nafisi et al. (2005) tested the use of a camera attached to the eyepiece of a light microscope to capture images of human semen. The authors developed an algorithm for sperm identification from lowcontrast images. Before analysis, images were processed because of the lack of proper contrast and sharpness. Extra particles were removed, then the background was subtracted, and finally sperm cells were selected based on morphologic measures and presence of a tail.

The algorithm was not used in a large number of samples and, therefore, the results were not expressive. Wilson Leedy and Ingerman (2007), focusing on accessibility, developed a free plugin (hereafter referred to as FCASA) for evaluation of zebrafish sperm using ImageJ, a free open-source java-based image processing software provided by the United States National Institutes of Health (Rasband, 2015). The authors used a phasecontrast microscope coupled to a high-speed camera via a $\mathrm{C}$-mount adapter. The system was developed to differentiate between bulk flow and moving cells and was validated by visual and statistical analyses, allowing applicability in future research.

Zebrafish sperm cells have a smoother track trajectory than mammalian sperm cells. A low accuracy was found in bull sperm motion analyses carried out using FCASA, a slow-speed camera (30 frames/s), and a light microscope (Elsayed et $a l ., 2015)$. FCASA could not initially differentiate between progressive and total motility. In 2017, Giaretta et al. optimized the plugin settings for the assessment of progressive stallion sperm motility. The present study aimed to test and validate FCASA settings for analysis of total stallion sperm motility under field conditions using a cell phone attached to a light-emitting diode (LED) microscope. 


\section{MATERIALS AND METHODS}

The experiment was approved by the Animal Ethics Committee of the Pontifical Catholic University of Paraná, Curitiba, Brazil (protocol no. 1021). The experimental apparatus included a light microscope (model B20,
Bioptika, Brazil) with LED illumination, a universal smartphone adapter (adapted from Goss, 2013) attached to the eyepiece (Figure 1A), and a Samsung cell phone (Galaxy S5, China, camera 16 megapixels) (Figure 1B). Videos were recorded at 59 frames per second and a resolution of $1920 \times 1080$ pixels.

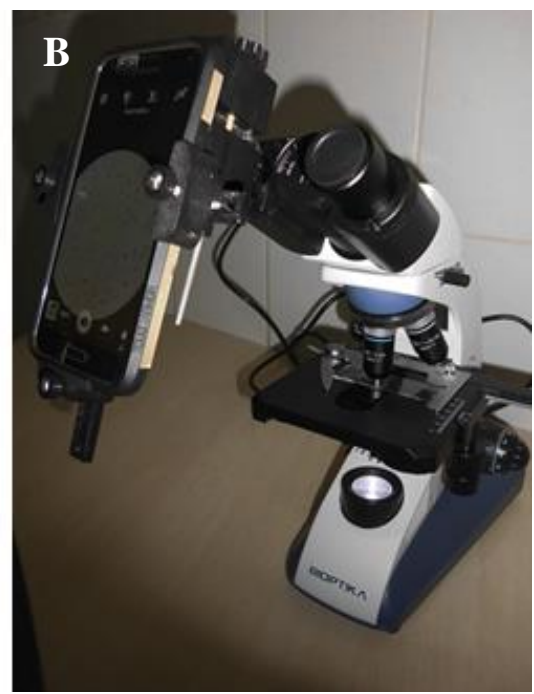

Figure 1. (A) LED microscope with a universal smartphone adapter attached to the eyepiece. (B) Cell phone placed on the adapter for video recording.

Semen collections were performed using a dummy mare and an artificial vagina (Conboy, 2011). Healthy Criollo ( $n=25)$, Appaloosa $(n=1)$, and Quarter-Horse $(n=4)$ stallions, from different private stables and without any history of reproductive disorders, were used in the study. The age of the animals ranged from 3 to 15 years. Stables were located in the outskirts of Curitiba $\left(25^{\circ} 25^{\prime} 40^{\prime \prime} \mathrm{S}\right.$ and $\left.49^{\circ} 16^{\prime} 23^{\prime \prime} \mathrm{W}\right)$, Paraná, Brazil. Because some stables did not have access to electricity, it would not be possible to perform all the analyses in the field; thus, for consistency, all samples were sent to the laboratory for evaluation. Collections were carried out between January and March 2016, during the breeding season.

A total of 48 samples were diluted 1:3 (v/v) in Botu-Sêmen extender (Botupharma, Brazil) and placed in a thermal box (BotuFlex, Botupharma, Brazil) at $5^{\circ} \mathrm{C}$ for transportation. At the laboratory, samples were diluted to a concentration of 20 to $50 \times 10^{6} \mathrm{sperm} / \mathrm{mL}$, when necessary. The time between sample collection and analysis ranged from 3 to $6 \mathrm{~h}$. After filtration (Nylon filter, IMV Technologies, France), the gelfree portion of samples was evaluated for sperm concentration using an improved Neubauer hemocytometer, in agreement with CBRA (Manual..., 2013) recommendations. Sperm count results were used for cooling and freezing calculations (Conboy, 2011; Sieme, 2011).

Twenty-two samples were randomly chosen for freezing, regardless of their motility, so as to obtain different motility values. Stallion semen samples were not tested for freezing capability. The number of frozen samples analyzed was limited by equipment availability and the distance between experimental sites and the CCASA facility. Aliquots of extended semen samples were centrifuged, and the cell pellet was resuspended in a sufficient volume of Botucrio freezing extender (Botupharma, Brazil) to obtain a concentration of $100 \times 10^{6}$ viable sperm cells/straw (final volume of $0.5 \mathrm{~mL}$ ). Straws were maintained at $5^{\circ} \mathrm{C}$ for $20 \mathrm{~min}$, held in liquid nitrogen vapor $(5 \mathrm{~cm}$ above the liquid nitrogen surface) for $20 \mathrm{~min}$, and stored in liquid nitrogen until use (Sieme, 2011).

For motility assessment, 1 drop $(10 \mu \mathrm{L})$ of sample was placed on a warm $\left(37^{\circ} \mathrm{C}\right)$ slide with a coverslip and video-recorded under an optical 
microscope at $400 \times$ magnification $(40 \times$ objective lens and $10 \times$ ocular lens). This magnification was chosen on the basis of preliminary tests showing that FCASA did not recognize sperm motility in cell phone videos captured using a $10 \times$ objective lens. Only one field was recorded per sample. Total motility percentage was evaluated by three methods: subjective visual analysis (SVA) by two technicians, FCASA (Wilson-Leedy and Ingermann, 2007), and a commercial CASA (CCASA) system (model IVOS, ISAS ${ }^{\circledR}$ V.1.2 computer system, Hamilton-Thorne Sperm Analyzer, Hamilton Thorne Research, Beverly, MA, USA).

Motility recordings of the cooled samples were first evaluated by SVA. Then, the same videos were assessed by FCASA for validation of the results (Amann and Hammerstedt, 1980; Schleh and Leoni, 2013; Elsayed et al., 2015). Frozen samples were first evaluated by CCASA. The same slides were then used to record videos for SVA and FCASA evaluation. Slides were kept at $37^{\circ} \mathrm{C}$ in CCASA, and the temperature was maintained during FCASA analysis using a warming plate attached to the light microscope. The video was recorded within $1 \mathrm{~min}$ after CCASA analysis to avoid major variations. The 48 cooled semen samples were evaluated by FCASA and SVA, and the 22 frozen semen samples were assessed by FCASA, SVA, and CCASA.

Videos were converted to mjpeg format for use with ImageJ. A total of 120 frames from the original video ( $2 \mathrm{~s}$, continuous) were selected, as fewer frames led to identification of insufficient sperm cells. If the field was changed manually while recording, FCASA would interpret the movement as sperm motility, altering the results. Therefore, it would be necessary to record and evaluate several videos per sample, compromising the practicability of the method. Videos were recorded without using the digital zoom feature of the camera to ensure high quality; as a result, images were circular. A square area was selected by using the crop tool, as shown in Figure 2.

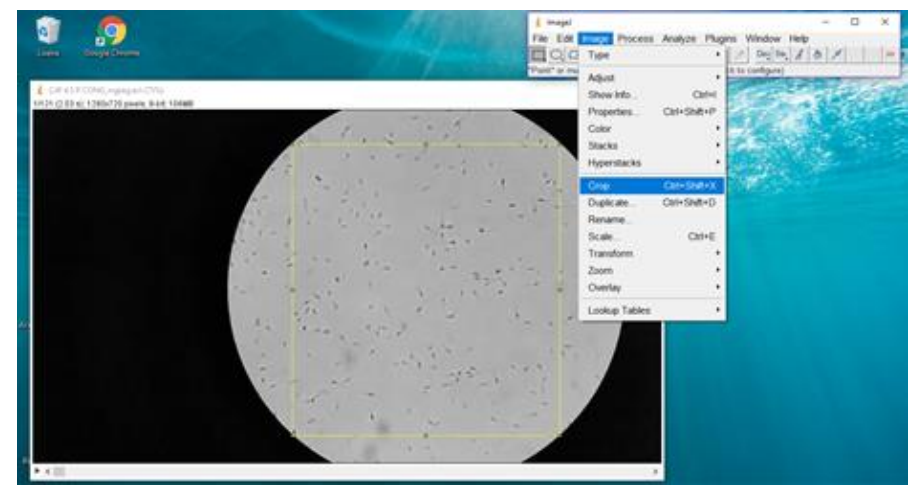

Figure 2. Use of ImageJ crop tool to select a square area for analysis by the free computer-assisted semen analysis (FCASA) package for ImageJ. The video was recorded using a LED microscope (40× objective lens and $10 \times$ ocular lens).

The background was subtracted using the appropriate tool, allowing sperm heads to be more prominent because of the increase in contrast (Figure 3A). The image was enhanced using the default black and white threshold, causing sperm heads to appear black on a white background (Figure 3B). The CASA plugin was then selected. The settings used for zebrafish sperm analysis appear automatically in the FCASA plugin. Because the plugin is very specific to the settings for which it was developed (Elsayed et al., 2015), it was not possible to correctly identify stallion sperm with the settings preestablished for zebrafish. After experimentation and visual comparison frame by frame, it was possible to identify the required modifications for stallion sperm cell identification. The modified settings were as follows: minimum sperm size $=1$, maximum sperm size $=250$, minimum track length $=20$, maximum sperm velocity between frames $=20$, and frame rate $=59$ (Figure 4). 


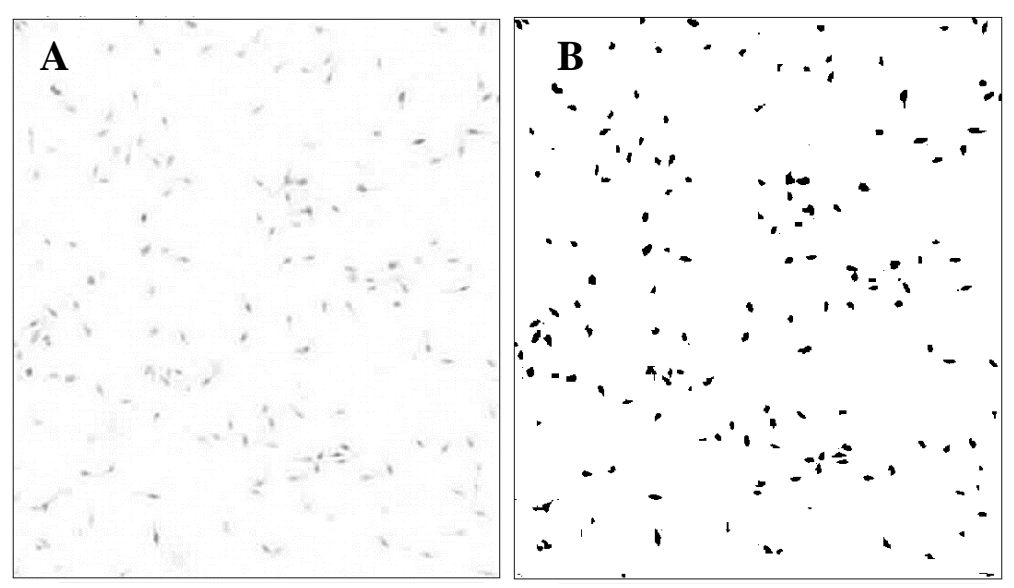

Figure 3. (A) Image of stallion sperm cells after background subtraction in ImageJ. (B) Stallion sperm cells after image enhancement with the threshold tool of ImageJ.

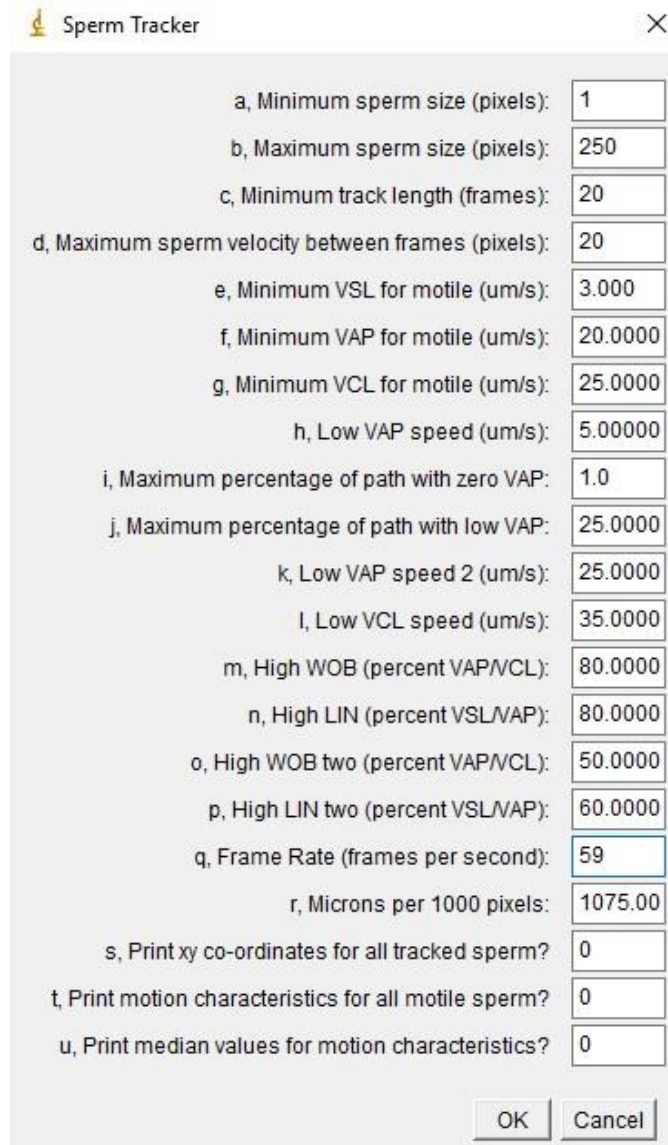

Figure 4. Settings used for stallion sperm motility analysis by the free computer-assisted semen analysis (FCASA) package for ImageJ.

The average time to analyze each sample, from video conversion to the final result, was calculated. The Friedman test was used for pairwise comparisons between SVA measurements (from both technicians) and FCASA, as data did not meet normality assumptions. Analysis of variance (ANOVA) was applied for pairwise comparisons of frozen 
samples between SVA, FCASA, and CCASA. The percent variation of FCASA from CCASA results was calculated. The chi-squared test was used considering CCASA as the gold standard to determine the percentage of correct estimates and errors obtained with FCASA and SVA. Estimates were considered correct when values were within a margin of error of $10 \%$ in relation to CCASA results. Pearson's correlation analysis was used to determine the correlation between CCASA and FCASA, and Spearman's correlation analysis for FCASA and SVA (considering the mean of both observations), as data did not have a normal distribution. All statistical analyses were performed using Statgraphics Centurion XVI (Statgraphics, 2009) software. Differences were considered significant at $P<0.05$.

\section{RESULTS AND DISCUSSION}

Amann and Waberski (2014) highlighted the importance of developing an accessible system for field theriogenologists, as CCASA systems are expensive and therefore not widely used. In this study, we developed a low-cost method with minimum equipment to analyze stallion sperm motility under field conditions using FCASA. The main obstacle was to generate good quality images, as FCASA is strongly dependent on image quality (Nafisi et al., 2005; Elsayed et al., 2015). Without the use of a phase-contrast microscope, sperm cells are not easily identified by the program, as reported in previous studies (Nafisi et al., 2005). We observed that a LED microscope generated higher-quality images than a microscope with a halogen lamp because the field was illuminated more uniformly, optimizing visualization, which is of high importance (Elsayed et al., 2015). It was also found that sperm cells were better identified at $400 \times$ magnification. An adapter was used to couple the cell phone camera to the microscope to ensure stability during recording.

First, we attempted to use an improved Neubauer hemocytometer for simultaneous determination of sperm motility and concentration in freeswimming sperm cells (Amann and Waberski, 2014). Cell movement within $0.1 \mathrm{~mm}$ depth chambers (the most common type) is natural and, therefore, the use of a correction factor is not needed. However, such chambers are too deep for accurate estimation by current CASA systems (Amann and Waberski, 2014), as cells frequently move out of focus (Elsayed et al., 2015). This effect was observed in the present study. Thus, total motility analysis was performed in a conventional slide. Several tests were made using FCASA to correctly track moving and static cells (Figure 5) before determination of optimal settings.

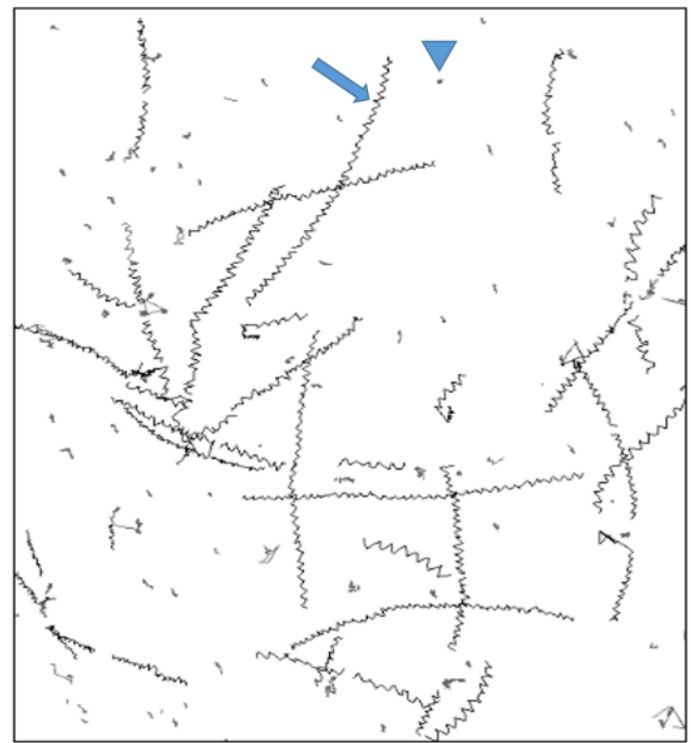

Figure 5. Representative image of stallion sperm motility analysis using the ImageJ plugin after determination of optimal settings. Mobile sperm cells were tracked (arrow), and static cells were identified (arrowhead). 
The Friedman test revealed that there were no significant differences between the 48 samples analyzed by SVA and FCASA $(P=0.46)$ or between the 22 frozen samples evaluated by SVA,
FCASA, and CCASA $(P=0.35$, Table 1$)$. This important finding shows that FCASA is comparable to routine subjective (SVA) and objective methods (CCASA).

Table 1. Total motility of stallion semen analyzed using a free computer-assisted semen analysis (FCASA) package for ImageJ, subjective visual assessment (SVA) by two technicians, and a commercial CASA (CCASA) system

\begin{tabular}{lcc}
\hline \multirow{2}{*}{ Method } & \multicolumn{2}{c}{ Total sperm motility $(\%)^{\text {(\%) }}$} \\
\cline { 2 - 3 } & $\begin{array}{c}\text { Cooled semen samples }^{\mathrm{a}} \\
(n=48)\end{array}$ & $\begin{array}{c}\text { Frozen semen samples }^{\mathrm{b}} \\
(n=22)\end{array}$ \\
\hline FCASA & 38.0 & $23.4 \pm 15.9$ \\
SVA - Technician 1 & 40.0 & $25.5 \pm 18.8$ \\
SVA - Technician 2 & 40.0 & $25.8 \pm 18.5$ \\
CCASA & - & $25.2 \pm 18.3$ \\
\hline
\end{tabular}

${ }^{a}$ Data did not satisfy normality assumptions and are presented as median values.

${ }^{\mathrm{b}}$ Data were normally distributed, and values are presented as mean \pm standard deviation.

No significant differences were observed between methods $(P<0.05)$.

$n=$ number of samples.

Sperm motility ranged from 0 to $99 \%$ in all samples. For stallions, the average motility of cooled semen for use in artificial insemination is about $70 \%$. The progressive motility of frozen semen, on the other hand, must be at least $30 \%$ for commercial use (Sieme, 2011; Manual..., 2013). In the present study, stallions were not previously tested for semen cooling or freezing capability and, in some cases, it was the stallion's first semen collection. Some stallions produce sperm cells that do not survive cooling because of intrinsic biochemical singularities (Conboy, 2011), a possible explanation for the low motility values of cooled semen samples. Because samples were frozen regardless of fresh motility, motility values differed greatly, resulting in an average total motility lower than $30 \%$.

The correlation between CCASA and FCASA was significant, positive, and strong ( $r=0.95, P<$ 0.0001 ). A scatter diagram comparing the results of both methods is shown in Figure 6. FCASA and SVA also correlated positively and significantly ( $r=0.90, P<0.0001$ ), evidence of the relationship of FCASA with other methods.

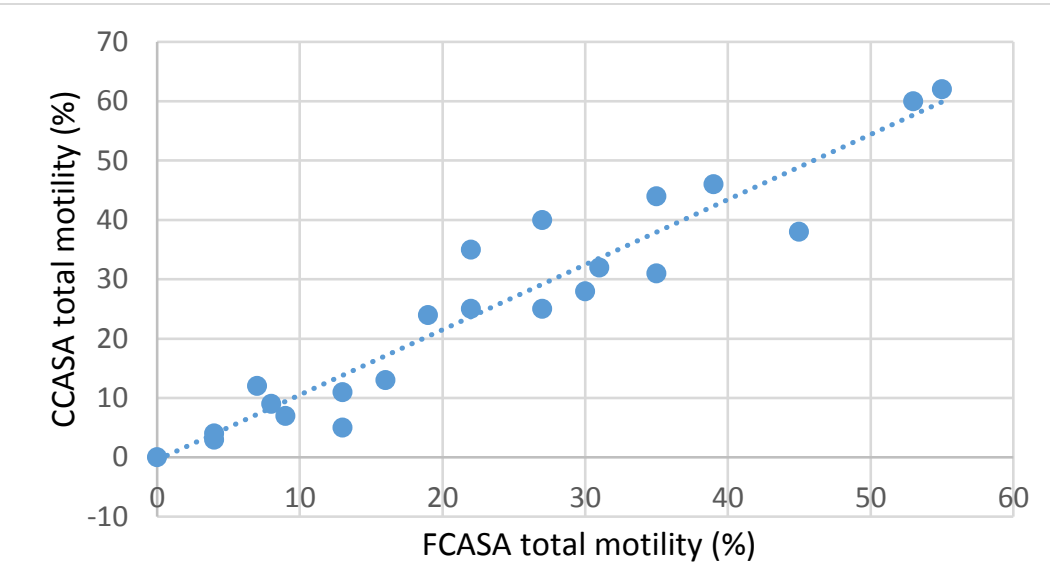

Figure 6. Scatter diagram of the total motility of 22 stallion sperm samples analyzed using a commercial computer-assisted sperm analysis (CCASA) system and a free CASA (FCASA) package for ImageJ. 
A chi-squared test was performed considering CCASA as the gold standard. Even though different CASA systems cannot be compared because of differences in their algorithms (Verstegen et al., 2002; Amann and Waberski, 2014), the aim of this analysis was to assess the ability of FCASA to generate similar results to CCASA. Only total motility was assessed, because, at the time the study was carried out, FCASA could not be used to evaluate progressive motility and because the parameter does not seem to depend strongly on the algorithm. A recent improvement was made to FCASA to allow analysis of progressive motility. Giaretta et al. (2017) analyzed 25 stallion sperm samples and proposed changes to the plugin settings to account for progressive motility and other parameters. The authors observed a high correlation between total percent motility and sperm cells with high mitochondrial membrane potential, which were considered viable.

In the present study, sperm concentration was determined by the standard method (Neubauer chamber counting) for calibrating samples for cooling and freezing. Concentration was not analyzed by FCASA or CCASA, as samples were analyzed in slides with coverslips. A previous study found that two different CASA systems were more strongly correlated with each other than with SVA; nevertheless, differences did not surpass 30\% (Jasko et al., 1990).

A $10 \%$ margin of error was considered in the chisquared test to account for differences between systems and field conditions. No significant differences were observed in the proportion of correct estimates or errors between FCASA and CCASA $(P=0.14)$, in contrast to the results reported by Elsayed et al. (2015). The authors tested FCASA with and without a phase-contrast microscope to analyze bull semen and found that the accuracy of the method without phase-contrast microscopy was $0.5-5 \%$. Differences in the number of correct, over-, and underestimates of sperm motility assessed by SVA compared with CCASA were significant, according to the chisquared test $(P=0.04)$, although means did not differ significantly by ANOVA. Table 2 presents the mean, standard deviation, overestimates, and underestimates of the three methods.

Table 2. Mean, correct estimates, overestimates, and underestimates of frozen stallion semen motility determined by subjective visual assessment (SVA) and a free computer-assisted semen analysis (FCASA) package for ImageJ in comparison with a commercial CASA (CCASA) system

\begin{tabular}{lcccc} 
Method & Total motility, $\%$ & $\begin{array}{c}\text { Correct estimates, } \\
n(\%)\end{array}$ & $\begin{array}{c}\text { Overestimates, } n \\
(\%)\end{array}$ & $\begin{array}{c}\text { Underestimates, } \\
n(\%)\end{array}$ \\
\hline FCASA & $23.4 \pm 15.9^{\mathrm{a}}$ & $20 / 22(91)$ & $0 / 22(0.0)$ & $2 / 22(9.0)$ \\
CCASA & $25.2 \pm 18.3^{\mathrm{a}}$ & $22 / 22(100)$ & $0 / 22(0.0)$ & $0 / 22(0.0)$ \\
SVA & $25.7 \pm 18.6^{\mathrm{a}}$ & $16 / 22(72.7)^{*}$ & $3 / 22(13.6)^{*}$ & $3 / 22(13.6)^{*}$ \\
\hline
\end{tabular}

Total motility is presented as mean \pm standard deviation. Means followed by different letters within a column differ significantly $(P<0.05)$. Correct estimates, overestimates, and underestimates are presented as number/total sample number and percentages (in parenthesis). A chi-squared test was performed to compare FCASA with CCASA and SVA with CCASA. An asterisk $\left(^{*}\right)$ represents a significant difference in relation to CCASA results.

On average, FCASA underestimated total motility $(23.4 \pm 15.9 \%)$ by $7.2 \%$ compared with CCASA $(25.2 \pm 18.3 \%)$. Underestimation is not as problematic as overestimation. Artificial insemination doses are calculated based on the number of viable sperm cells; thus, underestimation does not lead to an insemination dose with insufficient sperm cells but can reduce the number of viable doses produced by a single stallion (McKinnon et al., 2011). The percent variation between methods might be related to the efficiency of CASA systems. A previous study (Klimowicz et al., 2008) reported that computer analyses tend to be more critical and, therefore, sperm numbers are generally lower than those obtained visually.

In the present study, mean total motility values did not differ between methods, but significant overestimates and underestimates were obtained by SVA $(P<0.05$, Table 2$)$. The proportion of correct answers of FCASA did not differ from those of CCASA (the gold standard) according to the chi-squared test. Therefore, SVA is an overall precise method (as demonstrated by ANOVA) when carried out by experienced professionals 
(Amann and Waberski, 2014). However, when results were individually compared to the objective method, a significant error rate was observed. Therefore, it is recommended to use CASA systems to perform motility analyses, as the results are more accurate (Elsayed et al., 2015).

FCASA developers recommend using a phasecontrast microscope coupled to a high-speed camera. However, the use of this equipment in the field does not agree with the reality of Brazil. We found that FCASA was able to detect and correctly assess total stallion motility from images obtained using a light microscope and a cell phone camera (Samsung Galaxy S5 or superior), obviating the need for costly equipment. Elsayed et al. (2015) tested FCASA and reported that data obtained using optical microscopes are useful but those obtained with phase-contrast microscopes are superior. The authors also tested cameras with a rate of 30 frames/s and found that lateral movement of sperm cells was not captured correctly. With the settings established in this study, it was not possible to correctly perform the analysis with frame rates below 59 frames/s. Elsayed et al. (2015) also found that for comparisons between two different CASA systems, the frame rate should be at least 60 frames/s, as performed in this study for FCASA and CCASA.

The time spent to perform FCASA evaluations was short, $2.17 \pm 0.07 \mathrm{~min}$ per sample, including the time to convert the video, process the images, and perform the analysis. Total motility alone is not capable of estimating the reproduction potential of a male (Love, 2011), but the use of FCASA under field conditions opens new possibilities for research using accessible objective systems. The recent functions of FCASA should be tested for analysis of other sperm parameters.

\section{ACKNOWLEDGMENTS}

The authors thank Professors Marco Flávio Mattana, Alceu de Souza Britto Junior, Edson José Rodrigues Justino, Jacques Facon and Luis Fernando Fonseca Kasprzak from different areas of Pontifícia Universidade Católica of Paraná for the help with image analysis; Dr Marcilio Nichi from São Paulo State University for permitting the use of the commercial CASA; Dr Saulo Henrique
Weber for the help with statistical analysis; Pontifícia Universidade Católica of Paraná for the scholarship granted.

\section{CONCLUSION}

FCASA provided satisfactory results of total stallion sperm motility. The values were consistent with those of commercial systems. FCASA can be used to assess total motility in the field using low-cost equipment, such as a cell phone camera ( $\geq 59$ frames/s) attached to a light microscope by a universal smartphone adapter, combined with image processing and adequate plugin settings for stallions. The simple, effective method proposed in this study is innovative and accessible to field theriogenologists.

\section{REFERENCES}

AMANN, R.P.; HAMMERSTEDT, R.H. Validation of a system for computerized measurements of spermatozoal velocity and percentage of motile sperm. Biol. Reprod., v.23, p.647-656, 1980.

AMANN, R.P.; KATZ, D. Reflections on CASA after 25 years. J. Androl., v.25, p.317-325, 2004.

AMANN, R.P.; WABERSKI, D. Computerassisted sperm analysis (CASA): capabilities and potential developments. Theriogenology, v.81, p.5-17, 2014

CONBOY, H.S. Management of stallions in artificial insemination. In: MCKINNON, A.O.; SQUIRES, E.L.; VAALA, W.E.; VARNER, D.D. (Eds.). Equine reproduction. 2.ed. Iowa: Wiley Blackwell, 2011. p.1198-1207.

ELSAYED, M.; EL-SHERRY, T.M.; ABDELGAWAD, M. Development of computerassisted sperm analysis plugin for analyzing sperm motion in microfluidic environments using Image-J. Theriogenology, v.30, p.1-11, 2015.

GIARETTA, E.; MUNERATO, M.; YESTE, M. et al. Implementing an open-access CASA software for the assessment of stallion sperm motility: Relationship with other sperm quality parameters. Anim. Reprod. Sci., v.176, p.11-19, 2017.

GOSS, G. Universal camera phone/microscope adapter. 2013. Available: <https://www.thingiverse.com/thing:78071>.

Accessed on: December 12, 2015. 
JASKO，D.J.; LEIN，D.H.; FOOTE，R.H. A comparison of two computer-automated semen analysis instruments for the evaluation of sperm motion characteristics in the stallion. J. Androl., v.11, p.453-459, 1990.

KLIMOWICZ, M.D.; NIZANSKI, W.; BATKOWSKI, F.; SAVIC, M.A. The comparison of assessment of pigeon semen motility and sperm concentration by conventional methods and the CASA system (HTM IVOS). Theriogenology, v.70, p.77-82, 2008.

KUISMA, P.; ANDERSSON, M.; KOSKINEN, E.; KATILA, T. Fertility of frozen-thawed stallion semen cannot be predicted by the currently used laboratory methods. Acta Vet. Scand., v.48, p.14, 2006.

LINFORD, E.; GLOVER, F.A.; BISHOP, C.; STEWART, D.L. The relationship between semen evaluation methods and fertility in the bull. J. Reprod. Fert., v.47, p.283-291, 1976.

LOVE, C.C. Relationship between sperm motility, morphology and the fertility of stallions. Theriogenology, v.76, p.547-557, 2011.

LU, J.C.; HUANG, Y.F.; LÜ, N.Q. Computeraided sperm analysis: past, present and future. Andrologia, v.46, p.329-338, 2014.

MANUAL para exame andrológico e avaliação de sêmen animal. 3.ed. Belo Horizonte: CBRA, 2013. 104p.

MCKINNON, A.O.; SQUIRES, E.L.; VAALA, W.E.; VARNER, D.D. Equine reproduction. 2.ed. Iowa: Wiley Blackwell, 2011.

NAFISI, V.R.; MORADI, M.H.; NASRESFAHANI, M.H. Sperm identification using elliptic model and tail detection. World Acad. Sci. Eng. Technol., v.6, p.205-208, 2005.
NEUWINGER, J.; BEHRE, H.M.; NIESCHLAG, E. External quality control in the andrology laboratory: an experimental multicenter trial. Fertil. Steril., v.54, p.308-314, 1990.

RASBAND, W.S. ImageJ, U. S. National Institutes of Health, Bethesda, Maryland, USA, 1997-2018. Available: <https://imagej.nih.gov/ij/>. Accessed on: December 5, 2015.

SCHLEH, C.; LEONI, A. How to optimize the benefits of computer assisted sperm analysis in experimental toxicology. J. Occup. Med. Toxicol., v.8, p.6, 2013.

SIEME, H. Freezing semen. In: MCKINNON, A.O.; SQUIRES, E.L.; VAALA, W.E.; VARNER, D.D. (Eds.). Equine reproduction. 2.ed. Iowa: Wiley Blackwell, 2011. p.2972-2982.

STATGRAPHICS Centurion, X. V. I. Statpoint Technologies. INC. version, 16, 17. 2009.

VERSTEGEN, J.; IGUER-OUADA, M.; ONCLIN, K. Computer-assisted semen analyzers in andrology research and veterinary practice. Theriogenology, v.57, p.149-179, 2002.

WHITESELL, K.M.J.; MCDONNELL, S.M.; TURNER, R.M. Modernizing the stallion breeding soundness evaluation. J. Equine Vet. Sci., v.34, p.50-51, 2014.

WILSON-LEEDY，J.G.; INGERMANN， R.L. Development of a novel CASA system based on open source software for characterization of zebrafish sperm motility parameters. Theriogenology, v.67, p.661-672, 2007. 